\section{Battered Babies}

SIR,-Your leading article (20 September, p. 667) does less than justice to the possible contribution of family doctors to the battered babies and their families. Both the battered baby and the parent require not piecemeal help but long-term treatment and coordinated active social intervention. There is a sad lack of communication, let alone integration, between social workers and the profession. Having worked in a children's department as well as in general practice I can confirm what must be common experience, which is that the total background of these families is what needs assessment, and not the individual incident which brings the picture into focus.

Too much is made of the issue of confidentiality in relation to these cases. Many of us seem to have forgotten that confidential reports are dictated to secretaries, who may be private ones if we are lucky, but are more likely to be from the typing pool or even temporaries, and having disregarded confidentiality to this degree we proceed to make an immense fuss about passing on the reports to colleagues whose professional calling is not exactly the same as our own. It is unlikely that social workers and others who are banded together for the benefit of these patients are going to make unprofessional use of confidential information.

I would advocate closer liaison between family doctors and the social services, which could only serve to simplify the problems that these families impose on the community. We have to salvage the family as well as offer medical aid to the injured child.-I am, etc.,

Birmingham.

Bernard BarnetT.

\section{Metabolism in Parkinsonian Patients}

SIR,-Dr. F. Carswell and Dr. I. W. Dymock (12 July, p. 117) have commented on our communication dealing with metabolism in Parkinsonian patients (31 May, p. 552). It is encouraging to find that they too have found an abnormality in the intestinal absorption of $\mathbf{D}$-xylose in some of their Parkinsonian patients, confirming our observation. Their results suggest that this abnormality consists of a delayed absorption rather than malabsorption. In our patients anti-Parkinsonian drugs were discontinued several days before the tests were performed, suggesting that the abnormality was not related to the drug intake. Whether the differences between the patients and the control groups are merely secondary to autonomic nervous system disturbance in Parkinsonism, or have any bearing on the essential nature of the disease, is at present an unresolved though important question. It is at least of interest that one of the actions of a decarboxylase inhibitor RO IV 46.02 (Hoffman La Roche), which reduces considerably the required therapeutic dose of L-dopa, is to accelerate the absorption of this latter substance from the intestine. ${ }^{1}$

Dr. Carswell and Dr. Dymock state that the delay in absorption would render invalid the oral L-phenylalanine and L-tyrosine loading tests used by us for the investigation of the possible deficiency of tyrosine hydroxylase, as they are based on the assumption that the time course of the absorption of these amino-acids are the same in patients and controls. We would like to point out that no such assumption has been made by us in the interpretation of the results. On the contrary, we have suggested that, taking into account the presumably slow intestinal absorption of phenylalanine, the results of the loading tests were compatible with the hypothesis of a deficiency of tyrosine hydroxylase in Parkinsonian patients. A similar interpretation of our results was also suggested by the medical biochemistry correspondent in Nature. ${ }^{2}$

As we have stated in our communication, our observations are open to other interpretations because of the multi-diversional nature of phenylalanine and tyrosine metabolism. It is hoped that intravenous loading tests or preferably direct estimation of tyrosine hydroxylase activity in Parkinsonian patients will clarify the situation.-We are, etc.,

Department of Neurology,

$$
\text { J. BRAHAM. }
$$

Tel-Hashomer Government Hospital Tel-Aviv University Medical School, Israel.

\section{A. SZEINBERG.}

Institute of Chemical Pathology,
Tel-Hashomer Government Hospital, Tsrael.
Istiv

\section{REFERENCES}

1 Tissot, R., Presse Médicale, 1969, 77, 617. Tissot, R., Presse Medicale, 1969, 77,
Medical Biochemistry Correspondent, Nature,
1969 222, 1231.

\section{Survival after 195 Defibrillations}

SIR,-We have read with interest the letter from Dr. P. I. Parkinson and Dr. D. S. P. Dickson (19 July, p. 175) which appeared while we were preparing a report on a similar case.

A 56-year-old van driver was admitted on 9 May 1969 with an anteroseptal myocardial infarction. He was normotensive on admission. On the fourth hospital day he suddenly collapsed. Ventricular fibrillation was diagnosed and cardioversion promptly restored sinus rhythm. A few minutes later he went into ventricular fibrillation again. A slow infusion of lignocaine, $1 \mathrm{mg}$./ min., was started, preceded by an initial bolus of $50 \mathrm{mg}$. The next day the patient again went into ventricular fibrillation, became unconscious, cyanosed, and started to convulse. Sinus rhythm was restored by immediate counter shock. Up till midnight of the same day the patient was successfully counter-shocked for 12 attacks of

\section{Methoxyflurane for Obstetric Analgesia}

SIR,-Dr. J. S. Crawford's queries (30 August, p. 530) following our own series of papers (2 August, pp. 255, 259) are already adequately answered either in these or in previous publications. ${ }^{12}$

Inhalation of Agent for 3 or More Hours

\begin{tabular}{|c|c|c|c|c|c|c|c|}
\hline \multirow{2}{*}{\multicolumn{4}{|c|}{ Agent }} & \multirow{2}{*}{ No. of Babies } & \multicolumn{3}{|c|}{ Apgar Scores at 1 Minute } \\
\hline & & & & & $0-6$ & $7-9$ & 10 \\
\hline $\begin{array}{l}\text { Methoxyflurane } \\
\text { Pethidine } \\
\text { No pethidine } \\
\end{array}$ & $\because$ &.. & $\because$ & $\begin{array}{r}78 \\
28 \\
\end{array}$ & $\begin{array}{r}1 \\
1 \\
\end{array}$ & $\begin{array}{r}24 \\
5 \\
\end{array}$ & $\begin{array}{l}53 \\
22 \\
\end{array}$ \\
\hline Tctal & .. & .. & .. & $106(100 \%)$ & $2(2 \%)$ & $29(27 \%)$ & $75(71 \%)$ \\
\hline $\begin{array}{l}\text { Nitrous oxide/oxygen } \\
\text { Pethidine } \\
\text { No pethidine }\end{array}$ & $\mathrm{n}$ & $\begin{array}{l}. . \\
.\end{array}$ & $\begin{array}{l}\because \\
.\end{array}$ & $\begin{array}{l}44 \\
16 \\
\end{array}$ & $\begin{array}{l}2 \\
0 \\
\end{array}$ & $\begin{array}{r}17 \\
3 \\
\end{array}$ & $\begin{array}{l}25 \\
13 \\
\end{array}$ \\
\hline Total & .. &.. &.. & $60(100 \%)$ & $2(3 \%)$ & $20(33 \%)$ & $38(64 \%)$ \\
\hline $\begin{array}{l}\text { Trichloroethylene } \\
\text { Pethidine } \\
\text { No pethidine } \\
\end{array}$ &.. & $\because$. &.. & $\begin{array}{l}64 \\
18 \\
\end{array}$ & $\begin{array}{l}2 \\
1 \\
\end{array}$ & $\begin{array}{r}13 \\
1 \\
\end{array}$ & $\begin{array}{l}49 \\
16 \\
\end{array}$ \\
\hline Total &.. & .1 & .. & $82(100 \%)$ & $3(4 \%)$ & $14(17 \%)$ & $65(79 \%)$ \\
\hline
\end{tabular}

ventricular fibrillation. In between only rare ventricular extrasystoles were noted. The rate of lignocaine infusion was gradually increased to $5 \mathrm{mg} . / \mathrm{min}$. but with little effect.

The next day the patient was put on procainamide, $500 \mathrm{mg}$. four-hourly intramuscularly, instead of lignocaine. A day later, after 65 cardioversions in 17 hours, the administration of procainamide was changed to the intravenous route at 2 g. $/ 24$ hours. Acid-base state at that time showed $\mathrm{pH}$ to be $7 \cdot 45, \mathrm{PCO}_{2} 107 \mathrm{~mm}$. $\mathrm{Hg}$, and standard bicarbonate $50 \mathrm{mEq} / 1$. Plasma urea was $82 \mathrm{mg} . / 100 \mathrm{ml}$. Serum sodium 146 $\mathrm{mEq} / 1$. and potassium $3.1 \mathrm{mEq} / 1$. A regimen of $40 \mathrm{~g}$. of glucose with 20 units of insulin and $40 \mathrm{mEq}$ of potassium chloride per litre given intravenously at the rate of $2,000 \mathrm{ml}$. of the solution in 24 hours was started, and coninued for three days.

No beneficial effect was observed, and the patient had a further 45 attacks of ventricular fbrillation during 16 May 1969. At midnight he went into complete asystole, and it took four minutes to restart the heart. Acid-base state at this stage was $\mathrm{H}+38 \mathrm{nN}, \mathrm{pH} 7.42, \mathrm{PcO}$ $97 \mathrm{~mm}$. $\mathrm{Hg}$, and standard bicarbonate $45 \mathrm{mEq} / 1$. In the evening of the next day the patient's heart stopped again and cardiac massage for two minutes was required.

On 18 May, during a further attack of ventricular fibrillation, attempted cardioversion resulted in a complete asystole. Externa! cardiac massage was carried out, and, after about five minutes, the heart was restarted with ventricular fibrillation successfully converted to sinus rhythm. Plasma urea was then $72 \mathrm{mg} . / 100 \mathrm{ml}$., $\mathrm{pH} 7 \cdot 45, \mathrm{PcO}_{2} 107$ $\mathrm{mm} . \mathrm{Hg}$, and standard bicarbonate $51 \mathrm{mEq} / \mathrm{l}$. The intravenous procainamide was increased to $3 \mathrm{~g} . / 24 \mathrm{hrs}$. with no adverse effect on blood pressure. While on this regimen the patient had 21 further attacks of ventricular fibrillation, but the intervals between the last four attacks were considerably longer, and in the morning of 19 May his last ventricular fibrillation was successfully converted. This brought the total to 195 attacks of ventricular fibrillation with three episodes of complete cardiac standstill in six days. Further progress was uneventful and the patient was discharged on 7 July feeling very well.We are, etc.,

\section{Michael Kubik.} P. K. Das Gupta.

Burton Road Hospital Dudley, Worcs.

We can however furnish further information from the field trial about the effect of longer periods of inhalational analgesia on the baby (Table). There are no important or statistically significant differences between 